\title{
Degrees of Clarity and Obscurity in Chinese Images
}

Degrees of Clarity and Obscurity in Chinese Images

\section{Alfreda Murck}

\section{(2) OpenEdition}

\section{Journals}

Electronic version

URL: http://journals.openedition.org/extremeorient/94

DOI: 10.4000/extremeorient.94

ISSN: 2108-7105

Publisher

Presses universitaires de Vincennes

\section{Printed version}

Date of publication: 30 October 2008

Number of pages: $45-66$

ISBN: 978-2-84292-220-7

ISSN: 0754-5010

Electronic reference

Alfreda Murck, "Degrees of Clarity and Obscurity in Chinese Images », Extrême-Orient Extrême-Occident [Online], 30 | 2008, Online since 01 October 2011, connection on 30 April 2019. URL : http://

journals.openedition.org/extremeorient/94 ; DOI : 10.4000/extremeorient.94 


\title{
Degrees of Clarity and Obscurity in Chinese Images
}

\author{
Alfreda Murck
}

Hundreds of propitious images in Chinese culture have been systematically identified, yet much of the less visible, negative imagery remains to be catalogued. "Negative imagery" can be understood to include inauspicious portents, bad omens and curses as well as the kinds of visual evocations of complaints, sorrow, pathos, and frustration that appear in paintings of the educated elite. ${ }^{1}$ Did educated men of imperial China create obscure imagery to demonstrate erudition, or for pleasure, or personal security, or for all of these reasons? Whatever their motivations, this essay speculates on the nature of the relationship between the clear and obscure poles of expression.

One reason for the discrepancy in identifying various kinds of imagery is the relative difficulty of decoding. The 20th century efforts to catalogue positive images indicate that even those were not universally accessible. In 1920s Tianjin, assembling lucky images was an avocation of Japanese businessman Nozaki Nobuchika, who in 1928 published in Japanese the stilluseful reference Kisshô zuan kaidai (Explication of Auspicious Designs: A Study of Chinese Customs). ${ }^{2}$ He was followed by the British scholar C.A.S. Williams, whose Outlines of Chinese Symbolism and Art Motives was completed in 1932, published in 1941, and republished in a third revised edition in 1976. ${ }^{3}$ The publication of the Chinese translation of Nozaki's Explication of Auspicious Designs in 1980 contributed to studies both in the West and in Asia. As Terese Tse Bartholomew notes in the introduction to her book Hidden Meanings in Chinese Art, in the wake of the Chinese edition of Nozaki, over thirty books were published in Taiwan, China, and the West on various aspects of auspicious motifs. ${ }^{4}$ One of those was Wolfram Eberhard's The Symbolic Language of the Chinese: Hidden Symbols in Chinese Life and Thought. ${ }^{5}$ The "hidden symbols" and "hidden meanings" in the book titles by Eberhard and Bartholomew affirm that, to varying degrees, auspicious designs are characterized by culturally 
Figure 1. Trees of conjoined cosmic pattern (lianli mu). Hall of Imperial Peace (Qin'an dian), Palace Museum in the Forbidden City, Beijing. specific meanings that are not obvious to those of other cultures, or of later periods, or even to some within the culture. ${ }^{6}$

An example of an image commonly misunderstood by today's Chinese culture is found in the Imperial Garden that lies at the north end of the Forbidden City in Beijing. The image is a pair of trees that have grown together (fig. 1). In the meticulously designed ritual center of late imperial China, these trees (lianli $m u)$ grow on the symbolically significant Central Axis. They stand before the Hall of Imperial Peace, a Daoist temple that is the northernmost building within the Forbidden City. Guides inform their tour groups that this is a symbol of undying love, sometimes citing a couplet about the Tang dynasty emperor Minghuang (r. 712-756) and his besotted love for concubine Yang: "In heaven willing to fly on one pair of wings, / On earth willing to grow with branches entwined". ${ }^{7}$ Visitors nod at the familiar couplet and smiling couples pause to have their picture taken in front of the joined trees. Although valid for the 21st century visitors, the explanation is not as appropriate as the interpretation of the trees as an omen of the sovereign's superior virtue that spreads and harmonizes everything under its influence. This ancient omen is enumerated in early texts and depicted on the $\mathrm{Wu}$ Liang Shrine in Shandong province (fig. 2). ${ }^{8}$ The natural world responding to virtue, especially a sovereign's virtue, is a tenet of the ancient cosmology that posits a reciprocal interaction between heaven, man and earth.

This cosmology was deeply influential in the design of the Forbidden City in the early 15 th century. ${ }^{9}$ On 1 July 1917 , during the brief restoration of the Manchu monarchy, the last emperor, Puyi (1905-1967), was photographed in formal court robes in front of the Gate of Heaven's Primacy with the conjoined trees in the background (fig. 3). At that moment the conjoined trees were surely understood as symbolic of the unifying power of virtue. In recent decades, however, without the imperial ideology that surrounded the emperor, the image lost coherence; it was not intentionally hidden so much as forgotten 


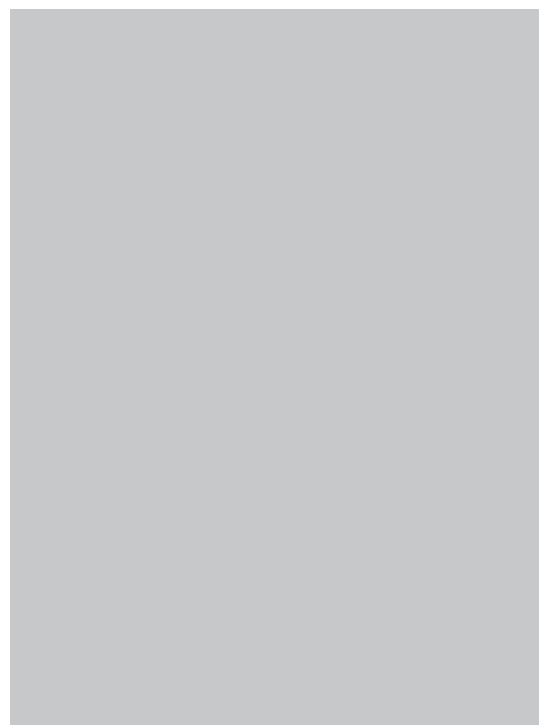

Figure 2. Joined trees as omen of royal virtue, ink rubbing. Wu Liang Shrine, 2nd century CE, Jiaxiang, Shandong. After Shane McCausland (ed.), Gu Kaizhi and the Admonitions Scroll, London: The British Museum Press in association with Percival David Foundation of Chinese Art, 2001, p. 179 , fig. 11.

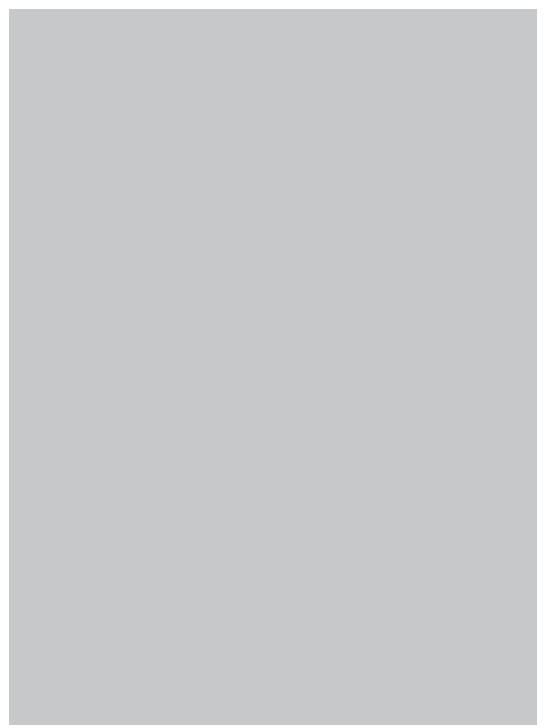

Figure 3. 1 July 1917, following restoration to the throne, Puyi stands in front of trees of conjoined cosmic pattern that grow inside the Gate of Heaven's Primacy, Hall of Imperial Peace (Qin'an dian), Imperial Garden, Palace Museum, Beijing. Courtesy of the Palace Museum, Beijing.

and overlaid by the story of the love match made in heaven. The conjoined trees that were originally an emblem of virtue became a sentimental symbol of undying love, both given legitimacy by their different texts.

If an overt symbol of unifying virtue is so easily forgotten, what of the more negative imagery that was deliberately hidden? The highly visible, relatively accessible metaphors of auspicious meaning and the more obscure metaphoric imagery of complaint and sorrow may seem to belong to entirely different realms. However, they have commonalities. They share a linguistic base, differing mainly in degree of clarity and concealment. The entire range of visual code perhaps can be thought of as having the shape of a comet, with the freely broadcast blessings clustering at the head, and the increasingly obscure puns and allusions steaming along, with the most difficult to comprehend sprinkled at the tail end, or even invisible to those outside the circle of the artist. ${ }^{10}$

What cultural forces underlay the resort to polite circumlocution and elaborate obscurity? First and foremost was the penchant for interpreting the 


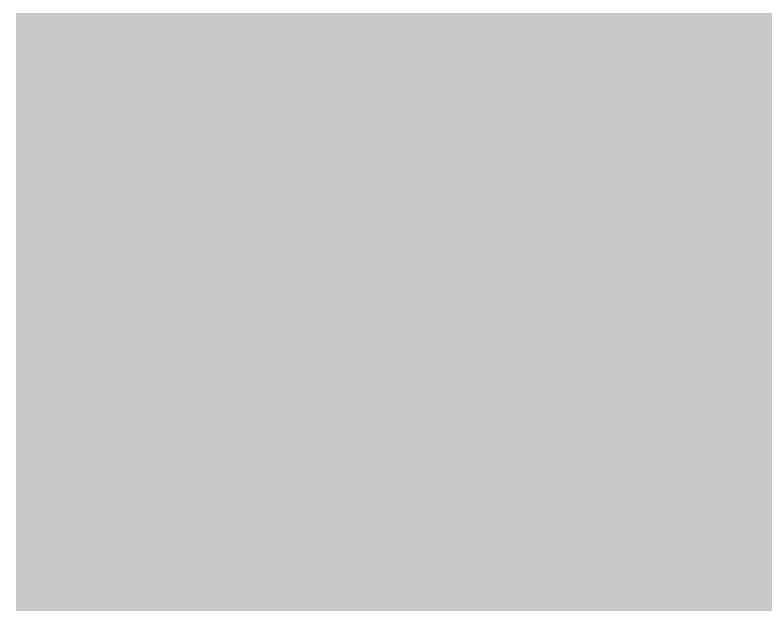

Figure 4. Puming Xuechuang (fl. 14th c.), Orchids, Bamboo and Rock (Yulan zhushi tu), undated (ca. 1340), hanging scroll, ink and pale color on silk, $34.0 \mathrm{x}$ $86.1 \mathrm{~cm}$, detail. Princeton Art Museum, Princeton University, Edward L. Elliott Family Collection.

natural world as signs and dynamic responses by heaven and earth to the behavior of man. By the Han dynasty (206 BCE-220 CE), the heavenly and earthly responses were beginning to be attributed to the magnanimous or despicable behaviors of rulers. Today, although belief in animism and most superstitions have been exorcised, many Chinese citizens consult almanacs to determine an auspicious day and hour for weddings (both to register the marriage and to hold a banquet) and acceptable times to conduct funerals. People are daily scanning the world for patterns that will help them to navigate treacherous situations to achieve successful outcomes. ${ }^{11}$

Another characteristic of Chinese discourse is the preference for indirection: the habit of speaking metaphorically, whether to express a compliment or a criticism. The function of indirect speech was to preserve "face", to avoid giving offense, and of course there was always the pleasure of finding similarities in diverse situations. ${ }^{12}$ In dynastic China, another factor was the penalty for speaking unwelcome opinions, which could lead to not only losing one's position, but also imprisonment, exile, financial ruin, or death for oneself and sometimes for one's entire family. Facing the threat of such punishments, men carefully considered their options including silence, circumspection, toadyism, and preparing one's coffin before speaking out.

A transparent and virtually universal metaphor can transcend social and linguistic barriers. Because of its natural connection to painful events and troublesome people, the thorn is one of the more easily understood metaphors. "They shall be as thorns in your sides" (The Book of Judges 2:3) is analogous to the Chinese equating the thorn with troublesome meddlers and social disorder. ${ }^{13}$ The 18th century poet Yuan Mei noted that in speaking of 
widespread trouble "in heaven and earth, thorns and brambles" was the sort of set phrase that "any village boy three feet high might have used". Perhaps near universal recognition is the reason why thorns were not named when a title was created for the elegant 14th century painting Orchid, Bamboo, and Rock by the Buddhist monk Xuechuang (fig. 4). Or perhaps it was the preference for indirection that led to reluctance to speak of something as nasty as thorns. The thorns stand between a splendid spray of cymbidium orchids (a symbol of the Superior Man (junzi) unappreciated) and a clump of bamboo (the Superior Man who is flexible enough to bend when buffeted by adversity but who stands upright again once the wind has passed). Whether posed with bamboo and orchids or with Chinese cabbage (bok choi, an emblem of the pure and honest official), thorns can be read as a reference to trouble. ${ }^{14}$ Cultural background is needed to understand the significance of orchids, bamboo, rocks and Chinese cabbage, but words are less necessary to convey the malevolent implication of the thorn.

An easily decoded visual image that requires only oral Chinese is the bat and blessings. Most Chinese-speaking people today readily equate the bats ( $f u$ 蝠) that appear on a host of decorative objects and contemporary greeting cards with the homophonous word "blessing" ( $f u$ 福). The Empress Dowager Cixi (1835-1908) in celebration of her fiftieth birthday had all five rooms in the Hall of Supreme Principle (Taiji dian) given quasi-European ceiling roundels decorated with five bats surrounding the character for longevity (pl. 8, p. 100). This popular rebus was "five blessings supporting long life" ( wu fu peng shou). The five blessings were usually identified as good luck, emoluments, longevity, health, and a natural death. Slightly more challenging is the rebus combining images of bats flying above ocean waves to create a wish for blessings as deep as the Eastern Sea (furu donghai). ${ }^{15}$ Judging from an informal survey, few modern Chinese can make out this rebus, although it was widely understood in the Qing dynasty (1644-1911).

How did painting become a vehicle for obscure allusions? Although admonitions, warnings, and complaints were present in texts written in the first millennia BCE, they entered painting relatively late. ${ }^{16}$ Instances are visible in the Northern Song (960-1127), the period when painting was rising in popularity among the educated elite. Steeped in literary expressions that offered scope for elegant indirection (that is, by painting literary metaphors to encode meaning), the literati were led by the brilliant and irrepressible scholarofficial Su Shi (1037-1101). Indirection was important because of potentially dire consequences: the painters were not professional illustrators, but officials in conflict with one another and sometimes with the court. Poetic metaphors 
enabled them to camouflage their sarcasm, injury, or injustice, which, had it been obvious, could have opened them to charges of lèse majesté. The official Zheng Xia (1041-1119), for example, was punished for his overly direct communication. To criticize an emperor's flawed judgment in appointing ministers, he submitted to the throne paintings of noble and vicious officials of the Tang dynasty (618-960). Emperor Shenzong (r. 1068-1085) did not appreciate his candor. Although Zheng Xia's life was spared, he was demoted and exiled to south China. ${ }^{17}$ His case became a warning to other painters and was likely an impetus to greater indirection. For those artists who could not resist commenting on politics and society, security came in the form of visual code that was vague or even incomprehensible to all but their closest friends.

By the 10th century, the category "painters" included two broad groups: the educated scholar-officials, who dabbled in painting as amateurs, and professional painters, whose representational skills were more accomplished. Scholar officials were highly educated gentlemen who in theory did not accept payment for their ink sketches. The categories were not absolute. Professional painters were sometimes well educated and even those who were not still had a grasp of the metaphors that densely populated their world. ${ }^{18}$ Over the centuries the high repute of literati ink painting became a saleable commodity and professionals mimicked with ease the styles and themes in paintings of the scholar class. Who were the recipients? And whether professional artist who imitated a literati theme or a wealthy patron who displayed the painting, did they comprehend the visual code? These are tantalizing and in most cases unanswerable questions. What is clear is that the difference in levels of comprehension was an essential condition for artists wishing to conceal complaints, insults, or sorrows in their paintings.

A set of paintings from about 1084 shows how one might poke fun at the foibles of political rivals. The sketches of eight small creatures probably would not be remembered today if their satirical implications had not been brought to the attention of Su Shi. Having just returned from four years in exile following a conviction for seditious poetry, Su Shi might have refrained from employing his wit. The reading of the images was guided by his eight quatrains that were clever enough to inspire someone to carve the designs into stone in the 12th century; these later served as a model for a 14th century painter [pl.9, p. 101]. ${ }^{19}$ Although the references to specific 11th century officials are uncertain, that is beside the point: the lampooning of personality and behavior is clear. A snail climbing a wall and getting stuck was said to refer to the overly-ambitious minister Wang Anshi (1021-1086). The section shown in Plate 9 has a toad on its back. The poem for the picture has been translated: "Its savage eyes, at whom do they glare? Its whitish belly swells 
in vain. Just take care not to worry the centipede. A hungry snake will never let you go free." ${ }^{20}$ Although this sort of painting typically was stored away as a handscroll or in book form and not available for public viewing, the complicated and dangerous relationships at court on which the poem and painting commented would have been obvious to any courtier who saw them.

Considerably more ambiguous was the message that resulted from the dissection of a character into its component parts, because that required recognizing a pattern of relationships. Unlike the rebus which works by voicing the depicted motifs to find verbal equivalents, this sort of painting is mute: naming the parts does not add up to a set phrase. For example, several insects painted at the bottom of a springtime scene might be an evocation of the character for "stupidity" (chun 蚌). In his recent satirical novel National Painting (Guohua), Wang Yuewen (1962-) portrays a minor official eager to please a senior official with a memorable gift. He prevails upon a reluctant artist to paint a cheerful spring scene. Only too late, after presenting the painting to the high official, does the minor official realize with mortification that two bugs (虫) beneath springtime (春) flowering shrubs were an insult. ${ }^{21}$ In this kind of painting, clarity of message was not a goal. On the contrary, obscurity and ambiguity were precisely what enables a subversive message to succeed. There is a double irony to the story in that the official, who was supposed to be superior in education and sophistication, did not see the pun being made by the mere "professional painter".

Still greater circumspection was necessary for educated men who wished to bemoan an unjust fate, especially if the injustice was the result of conflicts at court. If complaints were too explicit or if they blamed others, the accuser would give offense and invite more serious consequences. To vent frustrations without causing trouble for oneself, one's family and associates, the most useful images were those that relied on literary tropes and allusions that were difficult to access and that had more than one plausible explanation. Several motifs were taken from the early anthology The Songs of the South (Chuci). Gathered in the 2nd century CE, the core group of poems dating to several centuries earlier were attributed to an official of the State of Chu named $\mathrm{Qu}$ Yuan (legendary dates $c a 343-c a 277 \mathrm{BCE}$ ). Little is known about him beyond what is recorded in his 1st century BCE biography: absolutely dedicated to his king, he was slandered by political rivals, and was banished; he wrote poems declaring his loyalty, and, embracing a rock, he sank to his death in the Miluo River. ${ }^{22} \mathrm{Qu}$ Yuan came to exemplify the loyal but maligned official, a courageous poet who spoke truth to power. ${ }^{23}$ Much annotated over the centuries, the poems in The Songs of the South have been read as religious hymns, as artifacts of Chu culture, and as a kind of handbook for the 
disappointed bureaucrat. Although The Songs of the South was included in a 4th century anthology and its later recensions, the book was never part of the academic curriculum for the imperial examinations, so it was known to many, but certainly not all, officials.

A useful poetic trope evolved from the mention of falling leaves (luo mu) in the poem "Lady of the Xiang" (Xiang furen), one of The Nine Songs (Jiuge) in The Songs of the South. ${ }^{24}$ The falling leaf motif appears primarily in the art of the educated elite. According to annotations of the 2nd and 8th centuries CE, the falling leaves in "Lady of the Xiang" could allude to petty bureaucrats managing affairs while great talent was being wasted. ${ }^{25}$ Here we have a message that was not in the poem itself, but was concealed in the commentary to the poem. As a metaphor for the Superior Man, the falling leaf is strikingly at variance with the expectations in the Analects (Lunyu) of Confucius. Establishing a high standard of rectitude and moral principle for the Superior Man, Confucius disparaged the deciduous trees that change color when cold weather (i.e., adversity) arrives and praised the pine and cypress that remain constant. ${ }^{26}$ Given the dangerous conflicts that were a part of court culture, it was a noble but unrealistic ideal. Over the millennia the falling leaf was one of a repertoire of more forgiving comparisons for the moral and principled man.

In the strict hierarchy of the imperial court, there were times when great talent was put to minor use, and, like the leaf, blown about by uncomprehending bureaucrats. Perhaps it was the seriousness of that accusation that led to innocent explanations for falling leaves. A leaf falling to its root was said to evoke an elder returning to his hometown, and the phonetics of "falling leaf" (luo ye) led to the suggestion that it may be a pun on being content with one's occupation (le ye). ${ }^{27}$

Aside from the idea that talent was being wasted, we know from poetry that the falling leaf was a reflection on the brevity of life and the arbitrariness of death. An unexpected combination of events made the falling leaf an appropriate motif in the Southern Song (1127-1279). In 1126 the Northern Song capital, Kaifeng, was sacked by Jurchen troops. Following a four-month siege, the capital fell and the emperor, some 1300 people from the inner palace and as many as 3000 imperial clansmen plus officials, attendants and servants, were carried off as prisoners to the northern city Yanjing (modern Beijing) where many soon perished. ${ }^{28}$ Other clan members escaped capture and fled south under chaotic circumstances. Symbolically important to the restoration of the dynasty, Empress Meng (1077-1135) scrambled through Jiangxi province with an imperial guard, pursued at every step by Jurchen forces. The Empress and her small entourage survived near famine conditions 
and a mutiny by the guard escort. Having narrowly escaped disaster, the refugees settled in Jizhou which became an official clan center. Leaves tossed before the wind was a fitting metaphor for these clan members who must have wondered at their chance survival while so many others were lost. ${ }^{29}$ It is not impossible that the tea bowls made there at Jizhou took the metaphor of the falling leaf to reflect on death. Among the most beautiful tea bowls of the Song dynasty, they feature dark glaze and simple décor (pl. 10, p. 101) ${ }^{30}$ One of the names for the leaf décor bowl, perhaps coincidentally, uses the ancient "tree-leaf" (muye) from "Lady of the Xiang": "tree-leaf-pattern bowl" (muye wenyang wan). These tea bowls were used in private homes, tea houses and in Buddhist monasteries, where some refugees found shelter. The message encoded in this tea bowl may have reminded monks and imperial clan members alike of the impermanence of things, and of Wang Yi's annotation "great men govern anxiously, and the people worry. What's more, worthy men have been injured".

The falling leaf also appears in paintings of the Southern Song. Let us consider one painting in which the falling leaves are perfectly integrated with the narrative (fig. 5). The anonymous handscroll illustrates a canonical poetic text from the ancient Book of Odes (Shijing) and a poem that had been the subject of a court-sponsored series of paintings in the 12th century. ${ }^{31}$ "The Odes of Bin, Seventh Month" (Binfeng qiyue) was believed to be a guide to an ideal orderly society; it provides a poetic almanac of monthly activities and

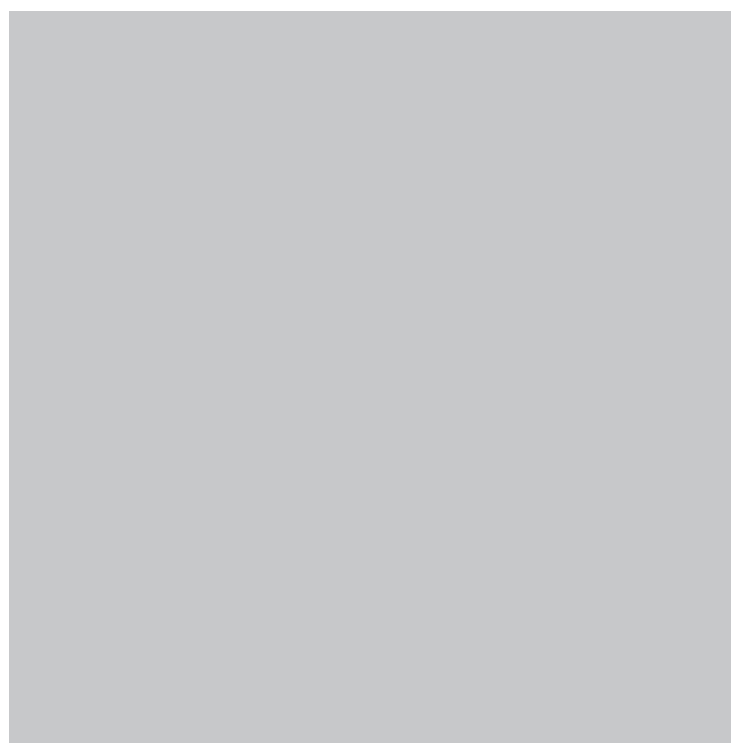

Figure 5. Unidentified artist, Southern Song, Odes of Bin, Seventh Month (Binfeng qiyue), undated handscroll (first half of 13th century), detail of chopping branches, ink on paper. The Metropolitan Museum of Art, John M. Crawford Jr. Collection, Gift of the Dillon Fund, 1982. 
reciprocal relationships in an agrarian society. The detail shown illustrates the lines "In the silk-worm month they gather the mulberry-leaves, take that chopper and bill to lop the far boughs and high." The figure in the tree is chopping branches so it is natural for leaves to be falling. And yet the depiction of leaves in the act of falling is very rare in the Chinese visual tradition. ${ }^{32}$ The camouflage is so perfect that one may feel it is perverse to see a lament in two leaves floating down or to read a reference to petty bureaucrats taking over or talent being wasted. However, there are reasons to suspect an ironic approach to the subject. The painting style is distinctly amateur (that is, it appears that a scholar is at work, not a polished professional capable of rendering wellproportioned human figures) and yet the motifs are sensitively rendered. And other details in the scroll are charmingly at variance with the orthodox presentation of the theme both at the imperial court and outside. ${ }^{33}$ We don't know who painted it or why, whether the painter was remembering someone recently deceased or was reflecting on a failed career, or was thinking of some other problem. The long handscroll was painted over many sessions, giving the feeling of a prolonged and ironic rumination on the ideal society proclaimed by the annotators of "The Odes of Bin, Seventh Month".

Buried deeper still are poetic lines that adopt the rhyme words of former poets to play on the ideas in the earlier poetic text. For example, in the 11th century when Su Shi for a second time was accused of slandering the emperor, he wrote a poem to the painter Wang Shen (ca 1048-after 1104) in which he use rhyme characters from a poem by the great Tang poet $\mathrm{Du} F u$ (712-770), "Autumn Day in Kui Prefecture, A Song Submitted to Supervisor Zheng and Adviser Li, in One Hundred Rhymes" (Qiuri Kuifu yonghuai fengji Zheng jian Li binke yibai yun). Su Shi didn't say that he was using Du Fu's poem for his rhyme words, and since Du Fu's “Autumn Day in Kui Prefecture” offered one hundred possible rhymes, it is easy to conclude that it was coincidental that Su Shi happened on identical rhymes, especially because Su did not observe the sequence of Du Fu's poetic rhymes. Su Shi, however, left many clues that he was thinking of Du Fu's "Autumn Day in Kui Prefecture". For one, he mimicked the phonetics of characters, so that Du Fu's "Blue Field" (qing tian 青田) became "two fields" (er qing tian二頃田). Another clue is found in Su Shi's playful manipulation of character structure: Su Shi took “wu” of Du Fu's Wu's sky (wu tian 吳天) and turned it upside down (吞). That is, $w u$ is written with a mouth radical over a sky element and tun, which means to swallow, is just the opposite. In Su's poem the sky is swallowed.

Further, in several places Su Shi did not use the rhyme character alone, but borrowed two or three surrounding characters, e.g., clouds and mist (yunyan), immortals (shenxian), boundless (momo), lovely (juanjuan), and drunken 
sleep (zui mian). Finally, Su Shi chose Du Fu couplets that are humorous and appropriate for his dilemma in 1088. For example, the last mentioned "drunken sleep" ends a Du Fu couplet that questions the advantages of court service: "Would you please explain: Incessantly attending morning audience - How can that compare to the security of drunken sleep?" In Su's poem "drunken sleep" ends a couplet with the surprise fall of snow from pine boughs: "In scarlet maples crows fluttered, companions to a waterside dwelling, From tall pines snow fell, startling my drunken sleep." ${ }^{34}$ The recipient Wang Shen discovered Su's poetic source and wrote back matching the rhymes with further references to "Autumn Day in Kui Prefecture"; Su Shi responded and Wang Shen reciprocated with a final poem. ${ }^{35}$

The four poems are related to an avant-garde painting. Datable to 1088, Wang Shen's radical Misty River, Layered Peaks (Yanjiang diezhang tu) is true to its title: unrolled from the right to left, the first two-thirds of the painting is undifferentiated mist shrouding a river (pl. 11, p. 102). The last third of the picture is a passage of densely layered mountains, presumably inspired by $\mathrm{Du}$ Fu's elegantly simple line "At times I am startled by layered peaks" (you shi jing diezhang). Because Du Fu's poem contains the important message that he could not see clearly (i.e., did not comprehend the situation) until autumn winds blew away the obscuring mist, I have argued that this is the underlying metaphor of the composition. ${ }^{36}$ It is possible to speculate that the juxtaposition of mist and mountains that subsequently became popular in Southern Song painting may have had its origins with Wang Shen's handscroll.

This elite form of encoding may have begun in the Tang dynasty, but in the 11th century it was practiced among scholars such as Huang Shu (10181058), his son Huang Tingjian (1045-1105), Su Shi, Su Che (1039-1112), Wang Shen, Qin Guan (1049-1100) and their circle. ${ }^{37}$

A few visual motifs evolved from rhyming word plays. One example is white plum blossoms painted in dripped ink wash to indicate a reversal of the normative order. Plum blossoms, admired for their hardiness, were a symbol of regeneration: they bloom at the end of winter when snow is still on the ground, and the blossoms appear before the leaves open. The dripped-ink plum image was created by the Chan (Zen) Buddhist monk Zhongren (ca. 1051-1123) of the Huaguang Monastery. He painted some for Huang Tingjian in response to a poem Huang had written matching earlier poems by Su Shi and others. The main poem of reference was written three centuries earlier by Du Fu. Du Fu was describing a new year's gathering at a moment of political crisis: the An Lushan rebellion was underway but it had yet to become very serious, and the rebels had not yet seized the capital. In the early 12th century, when Zhongren showed the manuscript to Huang Tingjian, twenty years had 
passed since the rhyming poems had been written; in retrospect it must have felt like an era of innocence when shared circumstances of exile were a cause for jocularity. In 1104 times had changed for the worse: these men who should have been at the top of the government were either dead (Su Shi and Qin Guan), or en route to a fatal exile (Huang Tingjian). ${ }^{38}$ Zhongren painted an expression of symbolic reversal: he created plum petals with drips of ink. Unlike the rebus that relies on phonetic equivalents, there is no linguistic phrase that can be equated with the painted motif, unless the viewer thought of the common phrase "turning white to black" (heibai diandao). Reflection was necessary to grasp the meaning, which may be one reason that this kind of ink painting came to be associated with Chan Buddhism.

Plum blossoms of the dripped-ink method were soon eclipsed by another painting technique. Late in Huizong's reign, around 1124, the technique of outlining plum blossoms with ink lines came into fashion, and because, among other considerations, outlined petals restored the flowers'whiteness, it became the imperially authorized and conventional way to paint flowering prunus. ${ }^{39}$ The dripped-ink plum blossoms were still painted and retained a strong association of dislocation and a world turned upside down. The idea of an unnatural reversal of white made black was still understood in the late 17th century when Bada Shanren (1626-1705) painted dripped-ink plum blossoms to vent his unhappiness at a failed marriage that had brought no son to continue his family line. ${ }^{40}$

The 18th century eccentric painter Jin Nong (1687-1763) claimed that the two approaches to painting plum blossoms were never used together in one work. Jin Nong would have been aware of their antithetical signification: one an affirmation of strength, purity and rejuvenation; the less-painted drippedink plum blossoms symbolizing an inversion of the world as it should be. Jin Nong maintained he was the first to combine them in one painting. His follower Luo Ping (1733-1799) produced a painting with a tangle of branches displaying outlined blossoms and dripped-ink blossoms (fig. 6). In the upperleft corner, Luo Ping transcribed his teacher Jin Nong's poetic quatrain with Jin's comment: "When the Pine-snow man of the Dao [Zhao Mengfu, 12541322] of the Yuan [1272-1368] painted flowers, he used only ink wash. When the Cooking Stone Mountain Farmer [Wang Mian, d. 1359] painted flowers, he used only outlines. No one before has combined the two techniques in one work, so I made this for my own amusement." ${ }^{41}$ Jin Nong, making light of his unorthodox combination, spoke of the two techniques as if they were only painting methods. And, consistent with preference for indirection, he did not explain their underlying meanings. Because life for Chinese scholars under the Manchu Qing was an amalgam of both good and bad, of opportunities and 
frustrations, the idea of two colors of plum may have had special appeal.

In exchanges with their most intimate friends, Chinese scholars contrived to communicate without words or traces. In literary criticism this kind of communication was called "hanging from antelope horns" (lingyang guajiao). The term was borrowed from the story of the Tang dynasty monk Yicun (822-908), who chided his students for seeking a formula to attain enlightenment. Wanting a specific method, he said, was like dogs sniffing the ground for a scent when their prey was not on the ground at all, but hanging from trees. (It was thought that antelopes escaped detection at night by hanging from tree branches by their horns.) Yicun said, "When I speak of this thing or that thing you concentrate all your effort on the pursuit of my words, in a chase after my phrases. But if I were like the antelope that hangs by its horns, where could you lay a hand on me ?" 42 The idea was used to describe poetic techniques, some say as early as the 8th century. In the 12th century this kind of communication that left no trace was discussed in the genre known as "talks on poetry" (shihua). The poetry enthusiast and critic Yan Yu (fl. 1200) said "hanging by antelope horns" described the Chan intuitive approach to poetry. ${ }^{43}$ Applied to painting, the colorful image had as much, or more, application than in literature.

In the mid-Qing dynasty the official and poet Weng Fanggang (1733-1818) wrote a lengthy poem of five characters per line for a painting commemorating $\mathrm{Su}$ Shi. $\mathrm{He}$ opened with the lines,

I have heard that men in antiquity did not

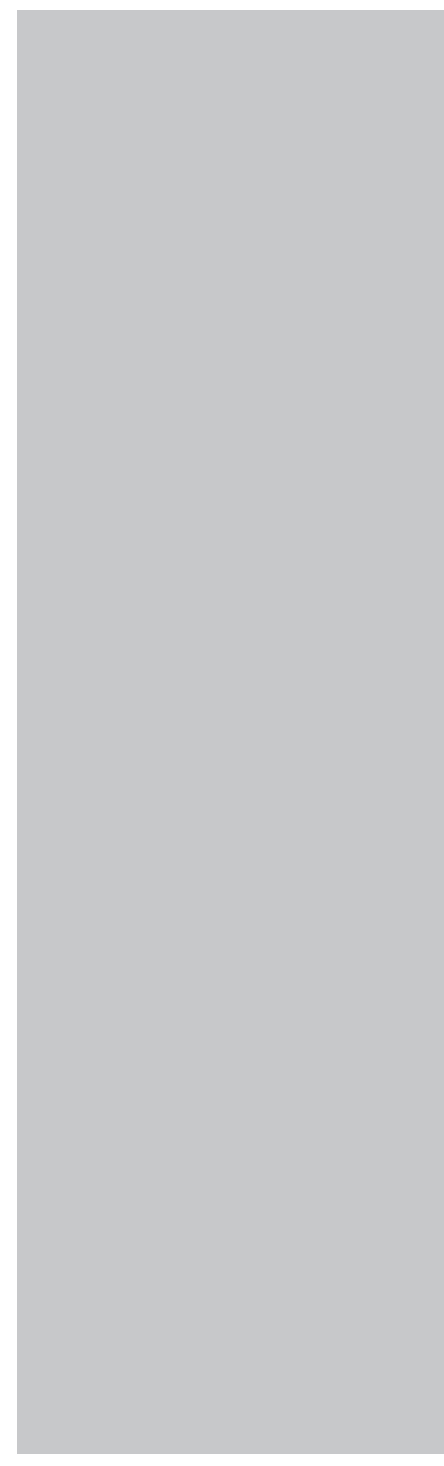

Figure 6. Luo Ping (1733-1799), Plum Painting in Two Tones (Erse meihua $t u$ ), hanging scroll, undated, ink on paper, $126.6 \mathrm{x}$ $27 \mathrm{~cm}$. Courtesy of the Palace Museum, Beijing. 
pass [techniques] on to others.

For example, those good at crafting uncut jade protected the process to the end.

Buddhists speak of antelope horns, of water-moon mirrors and silent blossoms. ${ }^{44}$

Weng Fanggang may have been alluding to the kind of encoding that $\mathrm{Su}$ Shi and his circle practiced, as described above, in which the poem being rhymed was recognized between like-minded friends but was not announced to others, ${ }^{45}$ or the kind of symbolic reversal that the monk painter Zhongren created with the dripped-ink plum blossoms.

The encoding that was practiced by educated painters takes us to the obscure end of the spectrum, to the tail end of the comet where traces are few and meanings are hard to access. The contrasts and continuities between the publicly-shared auspicious images and the less visible, allusive images of the educated elite are instructive. The following generalizations, while imprecise, are meant to stimulate discussion about the characteristics of this continuum.

Audience. Auspicious imagery was for everyone : the emperor, officials, and broader society, both literate and illiterate. Disgraced officials or commoners meeting ill fortune embraced auspicious images as much as anyone. Inauspicious images of complaint were shared and appreciated among much smaller circles of intellectuals. In some cases an artist created a work for himself. And inauspicious images of lament were employed only as the occasion arose, at times of grief or in sympathy with friends in distress.

Purpose. Auspicious pictures mark a favorable event or omen. They also anticipate potential disasters and try to mitigate them; they assert that the world is harmonious, and forecast happy outcomes in the future. Privately circulated images of distress, on the other hand, functioned to lodge a complaint, sympathize with a downtrodden friend, or vent frustration over an injustice.

Visuality. Auspicious paintings tend to be colorful and realistic, featuring polychrome flowers, fruits and animals emblematic of wishes such as longevity and continuity of the family line. Encoded images of resistance or complaint tend to be ink monochrome with assertive brushwork, often drawing on landscape themes.

Mood. Inside and outside the imperial court, the emblems of auspiciousness are joyful and positive, inspiring optimism, delight, and even awe. Most people then and now prefer happy outcomes. ${ }^{46}$ By contrast, images of lament or complaint are sometimes humorous, but more often restrained or bleak, pointing to a mood of melancholy.

Temporality. Auspicious images typically affirm the present and look 
optimistically to the future. In contrast, the paintings by and for discontents address their grievances and therefore necessarily look back to the unhappy experience that has triggered the expression.

Seasonality. Auspicious images were most often produced for the New Year, other seasonal events, weddings, and grand birthday celebrations; they therefore tend to be repetitive and are anticipated. The cheerful imagery exploit spring and summer when Yang is on the rise and the world is flourishing. Images of distress and opposition do not occur in any predictable cyclical patterns. Because they grow out of emotional strain, anger and frustrations, no matter what time of year the problem arises, the images are more likely to employ autumn and winter, the melancholy seasons of decline.

Consequences. Auspicious imagery was the norm and likely to be welcomed. Cheerful images (like stories with happy endings) were preferred by most people. On the other hand, painting a complaint or lament could precipitate censure, and if it was directed at the emperor, it could result in a charge of lèse majesté, a capital offense. When the painter Sheng Zhu (fl. late 14th century) served at the court of the Ming dynasty Hongwu Emperor (r. 1368-1398), he was well regarded. However, when commissioned to decorate a wall at a monastery, he painted a jellyfish riding on the back of a dragon, which was deemed offensive because the dragon was not exclusively but often a figure for the emperor. The Hongwu Emperor was displeased and had Sheng Zhu executed in public. ${ }^{47}$ The consequences of painting that image, whether the offense was intended or not, meant that it did not enter the painting repertoire. A further reason not to create negative images was the belief, or at least the fear, that images might induce the outcome depicted (just as sticking a pin in a doll might precipitate pain in an intended victim).

Display/Visibility. Auspicious images enjoyed high visibility. They were displayed in halls, posted by doorways, embroidered on clothing, and employed as decoration on a wide variety of porcelain, lacquer, and metal objects. ${ }^{48}$ Indeed certain Chinese characters themselves evolved into decorative patterns; longevity (shou), double-happiness (shuangxi), salary $(l u)$ are found on roof tiles and all manner of objects. ${ }^{49}$ The characters for the opposite phenomena - early death, unhappiness, poverty - were, of course, not used in decorative schemes. Rarely were inauspicious images employed as decorative elements. When they were, the visibility was elegantly understated, as in the Jizhou tea bowl of Plate 10. Images of lament, resistance, predation, and discontent were generally restricted to painting formats such as albums and scrolls that were stored away after viewing. Limited circulation could protect the artist from accusations of offending powerful people, and because many people believed that images could bring 
into reality the thing depicted, elaborate indirection (that is, a metaphorical depiction rather than a literal one) may have helped to prevent the precipitation of a bad outcome.

Sources and origins. Both kinds of visual expression have words and texts underlying them. Auspicious images were often based on puns and homophones, most of which are relatively easily deciphered. The most obscure of the auspicious messages feature metaphoric complexity, the product of an aesthetically educated elite. Although images of complaint do sometimes use puns and homophones, more often they rely on encoded literary references and therefore require greater knowledge and exegesis.

Orality. Auspicious wishes for wealth and longevity (such as "blessingsincome-longevity" fu lu shou, or "years without limit" wansui wujiang) or swift promotion in a career are easily named and spoken without hesitation. Phrases that lie behind or are embedded in negative imagery cannot be so readily named. Visual code for opposition are indirect references to whole stories or poems on unhappy events, so that even if one named a key phrase, only the cognoscenti would understand the reference.

Decorum. To observe decorum is to stay within the boundaries of acceptable behavior and to preserve one's good name. Auspicious images were to be widely shared on family and public occasions. Historically, criticism and complaint were to be discreet and private. Painting a silent criticism and storing it away in an album or handscroll conformed to the decorum expected of an official. Some things may be thought, but not stated publicly. To present a rebus containing an insult risked causing offense. Of course, the risk of violating decorum was part of the joke. When the recipient accepted and valued a gift that insulted him, the pleasure was likely all the greater.

Quantity. Because the repetition of lucky images served to multiply, strengthen, and broadcast the message, pictures that were socially acceptable and auspicious far outnumber those that were risky and socially unacceptable. Images of complaint form a small percentage of China's visuality. When China was ruled by Mongols (Yuan, 1278-1368), for whom many native Han Chinese had low regard, the incidence of images of protest rose. There were more unemployed Han scholars, the audience for images of discontent was larger, and the imagery more overt, perhaps because Chinese scholars felt confident that the Mongols did not understand the visual code.

Stability. Auspicious images are not only more visible, but also more stable and susceptible to definition. Images of complaint and sorrow are modified by personal circumstances, their designs are intentionally ambiguous, and their meanings get overlaid with innocent explanations. 
Images that have diverse meanings - such as the conjoined tree trunks, or the blossoming plum - require us to place them at several points on the cometshaped spectrum. Visual ambiguity raises interesting challenges for modern (and dynastic) scholars. The Chinese scholar who wanted to express his distress was successful when interpretations hovered between clear and obscure, between innocuous and critical, or between innocent and damning. Reading such visual images, whether obvious or hidden, requires alertness to strategies of indirection and to the artist's circumstances, as well as knowledge of historical and cultural contexts. In trying to understand Chinese visual codes, the challenge is to construct a credible interpretation from the literary record, historical fragments and deliberate silences.

\section{NoTeS}

1. Chinese vocabulary for prognostication of good fortune include terms that may be translated "good omen", "propitious portent" (jizhao, ruizhao, xiangzhao) and "auspicious" (jixiang). Imagery that was said to foretell disaster was called "ominous" or "inauspicious" (buxiang), or said to be an "evil omen" (ezhao, xiongzhao). For a study on Han dynasty bad portents see Hans Bielenstein, "Han portents and prognostications", Bulletin of the Museum of Far Eastern Antiquities, vol. 56, p. 97-112.

2. Nozaki Nobuchika catalogued and annotated 185 auspicious motifs. See also the Chinese translation Zhongguo Jixiang tu'an: Zhongguo fengsu yanjiu zhi yi (Explication of Auspicious Designs: A Study of Chinese Customs), Taipei, 1980 reprint of the 2nd ed. [Tôkyô, 1940] of Nozaki's Kisshô zuan kaidai, Tianjin, 1928.

3. Charles Alfred Speed Williams, Outlines of Chinese Symbolism and Art Motives: An Alphabetical Compendium of Antique Legends and Beliefs, As Reflected in the Manners and Customs of the Chinese, New York: Julian Press, 1960 reprint of the 3rd revised edition [Shanghai 1941] based on the 1st edition Peking: Customs College Press, 1931. A 4th revised edition was published by Tuttle Publishing in 2006.

4. Terese Tse Bartholomew, Hidden Meanings in Chinese Art, San Francisco : Asian Art Museum of San Francisco, 2006, p. 18.

5. First published in German as Lexikon chinesischer Symbole, Cologne: Eugen Diederichs Verlag, 1983; trans. in English by G. L. Campbell, The Symbolic Language of the Chinese: Hidden Symbols in Chinese Life and Thought, London and New York: Routledge \& Kegan Paul, 1986, and in French by H. Belletto, Dictionnaire des symboles chinois: symboles secrets dans l'art, la littérature, la vie et la pensée des Chinois, Paris, Seghers, 1984.

6. In modern times, in addition to auspicious imagery, scholars have catalogued 
local sayings, riddles that omit the last part of a common saying (xiehouyu), secret languages, tradesmen's jargon, linguistic taboos, and euphemisms (many of which are based on swear words in local dialect). See Endymion Wilkinson, Chinese History : a Manual, Cambridge, Mass.: Harvard University Asia Center for the Harvard-Yenching Institute, 2000, p. 84-86.

7. Bai Juyi (772-846), "Song of Everlasting Sorrow" (Chang hen ge). The poem recounts the love affair of Emperor Minghuang with the plump concubine Yang Guifei, and her execution at the hands of his troops, who held her responsible for the An Lushan rebellion of 756.

8. The "trees of conjoined cosmic pattern" are listed under good omens in Ouyang Xun (557-641) et al., Collection of Literature arranged by Categories (Yiwen leiju), juan 98. They are depicted on a stone slab at the Wu Liang Shrine, Shandong province, with the message "Interlocked trees appear when the ruler's virtue harmonizes and unifies everything in the eight directions" (mu lianli wangzhe de chun qia bafang weiyi) that is visible in Figure 2. Martin J. Powers, Art and Political Expression in Early China (New Haven and London: Yale University Press, 1991), p. 246-248, sees the interlocked trees as criticism, because the omen implied humane government that by comparison did not exist at the time of the $\mathrm{Wu}$ Family. If it was initially an implied criticism to encourage humane behavior, at some point the trees became an assertion of the ruler's merit and gardeners joined trees by cutting and grafting. In the Northern Song hanging scroll Palace Banquet (The Metropolitan Museum of Art), conjoined trees are a motif in the sumptuous palace courtyards, which may imply that the emperor's virtue brought harmony to the Inner Chambers. My thanks to Zoe Kwok for this example and interpretation.

9. In the Imperial Garden there are eight pairs of conjoined trees, the earliest of which is thought to date from the Jiajing reign (r. 1522-1566). See Du Chunlin and Yang Si, "Lianli mu" (Conjoined trees), in Palace Museum Journal (Gugong yuankan), 1980, no. 3, p. 96.

10. For thinking about the contrasts and correspondences between literary and visual expressions as well as methods of reading imagery, studies that have been particularly useful to me are Peter C. Sturman, "Cranes Above Kaifeng: The Auspicious Image at the Court of Huizong," in Ars Orientalis 20, 1990, p. 33-68, and "The Donkey Rider as Icon: Li Cheng and Early Chinese Landscape Painting," in Artibus Asiae 55, no. 1/2, 1995, p. 43-97; Ronald Egan, Word, Image, and Deed in the Life of Su Shi, Cambridge, Mass.: Harvard University Press, Council on East Asian Studies, 1994; Martin J. Powers, "Discourses of Representation in Tenth- and Eleventh-Century China," in Susan C. Scott (ed), The Art of Interpreting, Papers in Art History from The Pennsylvania State University, Vol. IX, 1995, p. 89-115; Julia K. Murray, "What is 'Chinese Narrative Illustration'?," in The Art Bulletin 80, 1998, p. 602-615; Maggie Bickford, "Emperor Huizong and the Aesthetic of Agency," in 
Archives of Asian Art, LIII/2002-2003, p. 71-104; Qianshen Bai, "Illness, Disability, and Deformity in Chinese Art," in Wu Hung and Katherine R. Tsiang (eds), Body and Face in Chinese Visual Culture, Cambridge, Mass.: Harvard University Press, 2005, p. 147-170.

11. Written charms, amulets, and incantations were enlisted to control unseen forces. Jan Jakob Maria de Groot observed that in the late nineteenth century, the populace was "engaged every day in a restless defensive and offensive war" against malevolent spirits. See Philip A. Kuhn, Soulstealers : The Chinese Sorcery Scare of 1768, Cambridge, Mass.: Harvard University Press, 1990, p. 104.

12. For example, the "Great Preface" to the Book of Odes (Shijing) describes the functions of the "Airs" (feng) as influence (of superiors on inferiors) and as criticism (of superiors by inferiors) but the indirection inherent in the odes preserve social decorum. See Stephen Owen, Readings in Chinese Literary Thought, Cambridge, Mass.: Harvard University, Council on East Asian Studies, 1992, p. 46-47.

13. David Hawkes, Ch'u Tz'u: The Songs of the South, An Ancient Chinese Anthology, Boston: Beacon, 1959, p. 26. Hong Xingzu (1090-1155) annotated, "Li Sao" in Chuci buzhu (Songs of Chu with supplementary annotations), Beijing: Zhonghua shuju, 1983, p. 19.

14. For images of thorns and green vegetables, see my essay «Paintings of Stem Lettuce, Cabbage, and Weeds: Allusions to Tu Fu's Garden », Archives of Asian Art, 48, 1995, p. 32-47. For Yuan Mei's comment, Arthur Waley, Yuan Mei, Eighteenth Century Chinese Poet, Palo Alto, CA: Stanford University Press, 1970 reissue of 1956 1st edition, p. 171.

15. Bartholomew, op. cit., p. 29.

16. Negative sentiments surface in some of the 305 poems in the Book of Odes datable to between $1000 \mathrm{BCE}$ and $600 \mathrm{BCE}$ and said to be songs of the people. For example Ode 113, "Big rat, big rat," implies criticism of and resistance to a greedy landlord. See Michael Nylan, The Five Confucian Classics, New Haven: Yale University Press, 2001, p. 80-81.

17. Alfreda Murck, Poetry and Painting in Song China: The Subtle Art of Dissent, Cambridge, Mass.: Harvard, 2000, p. 40. The paintings of virtuous and notorious officials that Zheng Xia submitted do not survive. They may have looked like "illustrations" and yet their intent was to communicate criticism. Professional painters and illustrators, of course, used indirection in their imagery whether for religious institutions or for the imperial court.

18. On the distinction between literati and professional painters and how collectors negotiated with them, see James Cahill, The Painter's Practice : How Artists Lived and Worked in Traditional China, New York: Columbia University Press, 1994, especially chapter two “The Painter's Livelihood”, p. 32-70. For an account of a scholar-painter par excellence marketing his work, see Craig Clunas, Elegant 
Debts: The Social Art of Wen Zhengming, 1470-1559, Honolulu: University of Hawaii Press, 2004, especially “'Friends, Clients, Customers", p. 113-140.

19. Deng Chun, Hua ji (Painting continued), in Yu Anlan annotated, Hua shi congshu (Compendium of texts on painting history), reprint [of Shanghai 1963] Taipei: Wenshizhe, 1974, vol. 1, p. 298.

20. Wu-chi Liu and Irving Yucheng Lo, Sunflower Splendor, Bloomington: Indiana University Press, 1975, p. 345. Su Shi, "Yong Xiucai hua caochong bawu" (Quatrains for paintings of small creatures by Examination Candidate Yong), in Su Shi shiji, Beijing: Zhonghua, 1982, juan 24, p. 1298. For the snail that was said to ridicule Wang Anshi, see Roderick Whitfield, Fascination of Nature: Plants and Insects in Chinese Painting and Ceramics of the Yuan Dynasty (12791368), Seoul: Yekyong, 1993, p. 37, and Murck, op. cit., p. 127-128.

21. Wang Yuewen, Guohua (National painting), Beijing: Renmin wenxue, 1999, p. 120.

22. Chu is the name of a state that ruled over much of south China and the Yangtze River region in the centuries prior to 221 BCE. For a translation of the earliest biography of Qu Yuan, see William H. Nienhauser, Jr. et al. (eds and trans.), Sima Ch'ien, The Grand Scribe's Records: The Memoirs of Pre-Han China, volume VII, Bloomington: Indiana University Press, 1994, p. 295-302. The site of Qu Yuan's drowning is commemorated today by five or six towns and shrines along the river; every summer dragon boats race in his memory.

23. David Hawkes, op. cit., p. 19. For an account of the uses of the Qu Yuan legend over the last two millennia, see Laurence A. Schneider, Madman of Chu: The Chinese Myth of Loyalty and Dissent, Berkeley: University of California Press, 1980 .

24. Hong Xingzu annotated, "Xiang furen", in Chuci buzhu, op. cit., p. 65. For a discussion see Murck, op. cit., p. 117-121.

25. The Han dynasty annotator Wang Yi ( $c a$ 89-ca 158) set the tone. For the line "Dongting waves, ah, tree leaves fall," he wrote, "It says that because autumn winds are strong, grasses and trees sway; the Xiang River has waves, and tree leaves fall. This is to say, great men govern anxiously, and the people worry. What's more, worthy men have been injured. Others say [that it means] Qu Yuan saw the autumn wind rising and tree leaves falling and grieved that the year was advancing to an end and he was getting old." In the early 8th century these themes were elaborated on by "The Five Ministers", who wrote a commentary on the Wenxuan. On the same line, they commented "[Falling leaves are] a metaphor for petty men (xiao ren) taking authority and therefore Great Men being cast away." Hong Xingzu annotated, "Xiang furen" in Chuci buzhu, op. cit., p. 65.

26. D. C. Lau (trans.), The Analects, New York: Dorset, 1979, 9.28, p. 100.

27. A leaf falling to its roots (or unable to get to its roots) is already used in the 13th century in the poetry of Lin Xiyi (1210-1273) and Zhang Fu (fl. 13th c.). For the 
pun, see Bartholomew, op. cit., p. 118.

28. John W. Chaffee, Branches of Heaven : A History of the Imperial Clan of Sung China, Cambridge, Mass. : Harvard University Asia Center, 1999, p. 113-120, 132-134.

29. Ibid., p. 120.

30. Robert D. Mowry, Hare's Fur, Tortoiseshell, and Partridge Feather: Chinese Brown- and Black-Glazed Ceramics, 400-1400, Cambridge, Mass.: Harvard University Art Museums, 1996, p. 36-39, 259-262.

31. For a history of the Song dynasty court-sponsored paintings, see Murray, $M a$ Hezhi and the Illustration of the Book of Odes, Cambridge, Eng.: Cambridge University Press, 1993.

32. Five or six leaves fall from a tree in a near contemporary handscroll by Mou Yi (1178-after 1242), Beating the Clothes (also titled Garments for the Beloved Ones), datable 1238-1240. The mood of lament is clearer since the painting is an illustration of a poem about women preparing clothes for husbands away at war. See Gugong minghua sanbai zhong (Three hundred masterpieces of Chinese painting in the Palace Museum), 6 vols., Taizhong, Taiwan: National Palace Museum, 1959, vol. 3, pl. 119.

33. Murck, op. cit., p. 245-252. Murray gives a survey of compositional types for Odes of Bin, Seventh Month in, "Patterns of Evolution in Chinese Illustration: Expansion or Epitomization?", in Cary Y. Liu and Dora C. Y. Ching (eds), Arts of the Sung and Yüan: Ritual, Ethnicity, and Style in Painting, Princeton: The Art Museum, 1999, p. 120-151.

34. The texts of the two poems are printed together for comparison in Murck, op . cit., p. 275-276. Explaining Su Shi's visual and verbal word plays has some of the dangers of explaining a joke - once laid out, it seems less funny. His poems, however, hold up very well, and it is easy to imagine that the original composition and discovery of allusions was great fun for both participants.

35. The four poems that were exchanged between $\mathrm{Su}$ and Wang Shen are translated and discussed in Murck, op. cit., chapter six: "Su Shi and Wang Shen: Misty River, Layered Peaks", p. 126-156.

36. Ibid., p. 135.

37. Murck, op. cit., chapters six and seven, p. 126-188.

38. Ibid., p. 180-184.

39. For the wide range of meanings of the flowering prunus in poetry and painting see Bickford, Ink Plum: The Making of a Chinese Scholar-Painting Genre, Cambridge, New York: Cambridge University Press, 1996.

40. For a brief account of the ink-dripped plum blossom, see Murck, "Public and Private Truths in Chinese Painting: Zhu Da and Fu Baoshi", for Bridges to Heaven: Festschrift in Honor of Wen C. Fong, P.Y. and Kinmay W. Tang Center 
for East Asian Art, Princeton University, forthcoming.

41. Jin Nong's art history is flawed: Zhao Mengfu was not a plum blossom painter (one wonders what Jin Nong saw to inspire the comment), and while Wang Mian was a master of ink-outlined plum blossoms, he did at least one ink-dripped plum blossom painting. For more information on Luo Ping's painting see Eccentric Visions: The World of the Chinese Artist Luo Ping, exhibition catalogue, Museum Rietberg, Zurich, forthcoming.

42. Adele Austin Rickett, Chinese Approaches to Literature from Confucius to Liang Ch'i-ch'ao, Princeton: Princeton University Press, 1978, p. 3. For the original Daoyuan comp., Chuan deng lu (Record of the Transmission of the Lamp), published 1004.

43. Yan Yu, Canglang shihua (Canglang poetry talks), in He Wenhuan, comp. Lidai shihua (Anthology of chats on poetry), 1740, reprinted in 1 vol., Taipei: Yinwenguan, 1983.

44. Weng Fanggang inscription for Luo Ping, "Su Shi's Travels", album, Collection of Wan-go Weng, in Eccentric Visions: The World of the Chinese Artist Luo Ping, op. cit. The translation is my own.

45. Three examples of this encoding process were discussed in my Poetry and Painting in Song China, in chapter 6, "Wu Shi and Wang Shen : Misty River, Layered Peaks", p. 126-156, and chapter 7, "Huang Tingjian's Laments”, p. 157-188.

46. Dore J. Levy shows how a painful true story was redeemed with a happy ending in "Transforming Archetypes in Chinese Poetry and Painting: The Case of Ts'ai Yen," in Asia Major, vol. 6 part 2, p. 147, 161-62. The preference for happy endings is not unique to dynastic China. A survey of British readers published on World Book Day 2006 revealed that 41 percent of those polled were "overwhelmingly in favour" of books with happy endings, compared with 2.2 percent who sought out sad endings (Dalya Alberge, London, March 2006).

47. Nie Chongzheng, "Qing dai gongting huihua gaishu" (Summary of Qing dynasty court painting), on www.chinaculture.com.cn/ww/jz/1.htm, citing Xu Qin, Ming hua lu (Record of Ming painting), juan 2. My thanks to Michele Matteini for alerting me to this example.

48. Jessica Rawson, "The Auspicious Universe", in the exhibition catalogue China: The Three Emperors, 1662-1795, London : Royal Academy of Arts, 2005, p. 356381.

49. For a playful use of the character "longevity" in 18th-century Japan, see Marianne Simon-Oikawa's paper in this volume (p. 156-157). 
Degrees of Clarity and Obscurity in Chinese Images

\section{GLOSSARY}

An Lushan (703-757) 安祿山

Bada Shanren (1626-1705) 八大山人

Bai Juyi (772-846) 白居易

Beijing 北京

Binfeng qiyue 䯚風七月

bok choi 白菜

buxiang 不祥

Canglang shihua 滄浪詩話

Caochong bawu 草蟲八物

Chan (Zen) 禪

Chang hen ge 長恨歌

Chuan deng $l u$ 傳燈錄

Chuci 楚辭

Chuci buzhu 楚辭補注

chun 蚌

Cixi (1835-1908) 慈禧

Daoyuan 道原

Deng Chun (fl. 12th c.) 鄧椿

Dongting (lake) 洞庭

$\mathrm{Du} \mathrm{Fu}$ (712-770) 杜甫

Erse meihua tu 二色梅花圖

ezhao 惡兆

feng 風

fu lu shou 福祿專

furu donghai 福如東海

Guohua 國畫

Han (dynasty) 漢

Hangzhou 杭州

He Wenhuan (fl. late 18th c.) 何文煥

heibai diandao 黑白顛倒

Hong Xingzu (1090-1155) 洪興祖

Hongwu (r. 1368-1398) 洪武

Hua ji 畫繼

Hua shi congshu 畫史叢書

Huaguang si 華光寺

Huang Shu (1018-1058) 黃庶

Huang Tingjian (1045-1105) 黃庭堅

Huizong (1082-1135) 徽宗

Jiajing (r. 1522-1566) 嘉靖

Jianbaizi (fl. early 14th c.) 堅白子 


\section{Alfreda Murck}

Jiangxi (province) 江西

Jin Nong (1687-1763) 金農

Jiuge 九歌

jixiang 吉祥

jizhao 吉兆

Jizhou 吉州

juanjuan 娟娟

junzi 君子

Kaifeng 開封

Kisshô zuan kaidai 吉祥圖案解題

le ye 樂業

Li Sao 離騷

lianli mu 連理木

Lidai shihua 歷代詩話

Lin Xiyi (1210-1273) 林希逸

lingyang guajiao 羚羊掛角

$l u$ 祿

Lunyu 論語

lиo mu 落木

Luo Ping (1733-1799) 羅聘

luo ye 落葉

Meng (Empress) (1077-1135) 孟太后

Miluo (river) 汨羅

Ming (dynasty) 明

Ming hua lu 明畫錄

Minghuang (r. 712-756) 明皇

momo 漠漠

Mou Yi (1178-after 1242) 牟益

mu lianli wangzhe de chun qia bafang weiyi 木連理王者德純洽八方為一

muye wenyang wan 木葉文樣碗

Nozaki Nobuchika 野崎誠近

Ouyang Xun (557-641) 歐陽詢

Puming Xuechuang (fl. 14th c.) 普明雪窗

Puyi (1905-1963) 溥儀

Qin Guan (1049-1100) 秦觀

Qin'an dian 欽安殿

Qiuri Kuifu yonghuai fengji Zheng jian Li binke yibai yun 秋日县府咏怀奉寄郑 监李宾客一百韵

Qu Yuan ( ca 343-ca 277 BCE) 屈原

ruizhao 瑞兆

Shandong (province) 山東

Sheng Zhu (fl. late 14th c.) 盛著 
Degrees of Clarity and Obscurity in Chinese Images

shenxian 神仙

Shenzong (r. 1068-1085) 神宗

shihua 詩話

Shijing 詩經

shou 專

shuangxi 雙喜

Song (dynasty) 宋

Su Che (1039-1112) 蘇轍

Su Shi (1037-1101) 蘇軾 (or Su Dongpo 蘇東破)

Taiji dian 太極殿

Tang (dynasty) 唐

Wang Anshi (1021-1086) 王安石

Wang Mian (d. 1359) 王冕

Wang Shen (ca 1048-after 1104) 王詵

Wang Yi (ca 89-ca 158) 王逸

Wang Yuewen (1962 -) 王跃文

wansui wujiang 萬歲無疆

Wenxuan 文選

Weng Fanggang (1733-1818) 翁方網

wu fu peng shou 五蝠捧專/五福捧覀

Wu Liang ci 武粱祠

Xiang (river) 湘

Xiang furen 湘夫人

xiangzhao 祥兆

xiao ren 小人

xiehouyu 歇後語

xiongzhao 凶兆

Xu Qin 徐沈

Yan Yu (ca. 1200-after 1270) 嚴羽

Yang Guifei (719-756) 楊貴妃

Yangtze (river) 長江

Yanjiang diezhang $t u$ 煙江且嶂圖

Yanjing 燕京

Yicun (822-908) 義存

Yiwen leiju 藝文類聚

Yong Xiucai hua caochong bawu 雍秀才畫草蟲八物

you shi jing diezhang 有時驚疊嶂

Yu Anlan 于安瀾

Yuan (dynasty) 元

Yuan Mei (1716-1798) 袁枚

Yulan zhushi tu 玉蘭竹石圖 


\section{Alfreda Murck}

yunyan 雲煙

Zhang Fu (fl. 13th century) 章甫

Zhao Mengfu (1254-1322) 趙孟煩

Zheng Xia (1041-1119) 鄭俠

Zhongren (ca 1051-1123) 仲仁

zui mian 酔眠 